\title{
UPAYA PENINGKATAN HASIL BELAJAR FAKTOR DAN KELIPATAN BILANGAN MELALUI METODE CTL
}

\author{
Muryatin \\ SDN Pakunden 1, Jalan Bogowonto 48A Kota Blitar \\ E-mail: muryatin2@gmail.com
}

\begin{abstract}
Improvement Efforts of Learning Outcomes in Factors and Multiples Numbers Lesson by CTL Method. This study aimed to describe the implementation of CTL model in math learning. This study used a qualitative approach. The type of this research was classroom action research with two cycles, each cycle consisted of two meetings. The results showed that in the first cycle, the completeness of classical learning was $44 \%$ and in the second cycle increased up to $88 \%$, so it can be concluded that the mathematics learning material factors and multiples of numbers through CTL model can improve student learning outcomes.
\end{abstract}

Keywords: learning outcomes, factors and multiples number, CTL method

\begin{abstract}
Abstrak: Upaya Peningkatan Hasil Belajar Faktor dan Kelipatan Bilangan melalui Metode CTL. Tujuan dari penelitian ini adalah mendeskripsikan penerapan model CTL pada pembelajaran matematika. Penelitian ini menggunakan pendekatan kualitatif. Jenis penelitian yang digunakan adalah penelitian tindakan kelas, yang terdiri dari dua siklus, masing-masing terdiri dari dua pertemuan. Hasil penelitian ini menunjukkan bahwa pada siklus I ketuntasan belajar klasikal memperoleh presentase sebesar $44 \%$ dan pada siklus II meningkat menjadi $88 \%$, sehingga dapat disimpulkan bahwa pembelajaran matematika materi faktor dan kelipatan bilangan melalui model CTL dapat meningkatkan hasil belajar siswa.
\end{abstract}

Kata kunci: hasil belajar, faktor dan kelipatan bilangan, metode CTL

Proses pembelajaran di SDN Pakunden 1 Kota Blitar, guru masih banyak menggunakan metode ceramah. Hal tersebut menyebabkan siswa menjadi kurang aktif dan menjadi bosan dalam mengikuti proses pembelajaran, sehingga hasil belajar yang diperoleh masih terbilang rendah. Nilai ketuntasan minimal siswa yang ditetapkan oleh sekolah dalam proses belajar mengajar secara kognitif, pada pelajaran Matematika Kelas 4 adalah 70 . Berdasarkan hasil observasi awal, diperoleh daftar nilai kelas 4 SDN Pakunden 1 Kota Blitar tahun pelajaran 2015/2016 pada pelajaran Matematika sebagai berikut: dari 25 orang jumlah siswa hanya 10 siswa atau $40 \%$ yang memenuhi standar ketuntasan sedangkan sisanya yaitu 15 siswa atau $60 \%$ masih dibawah standar nilai ketuntasan.
Maka dari itu peneliti mencoba menerapkan model pembelajaran Contextual Teaching Learning (CTL), yang nantinya diharapkan akan dapat meningkatkan hasil belajar siswa terutama dalam menyelesaikan soal-soal pada materi pokok faktor dan kelipatan bilangan. Diperlukan metode pembelajaran yang tepat dalam meningkatkan hasil belajar faktor dan kelipatan bilangan, yaitu dengan menerapkan model pembelajaran CTL.

Secara umum, belajar adalah suatu aktivitas mental atau psikis, yang berlangsung dalam interaksi aktif di lingkungan, dan menghasilkan perubahan-perubahan dalam pengetahuan, pemahaman, keterampilan dan nilai perubahan sikap yang bersifat konstan dan membekas. Menurut 
merupakan proses internal yang kompleks. Proses internal tersebut melibatkan seluruh mental yang meliputi aspek-aspek kognitif, afektif, dan psikomotorik. Dari berbagai pendapat tersebut, dapat disimpulkan bahwa belajar merupakan usaha mengubah tingkah laku yang akan membawa perubahan pada individu, misalnya dalam hal penambahan ilmu pengetahuan, kecakapan, keterampilan, dan sikap.

Menurut Subarinah (2006), pembelajaran matematika, terutama di sekolah dasar, dilaksanakan berdasarkan temuan-temuan ahli jiwa tentang pentingnya memahami tingkat berpikir siswa. Oleh karena itu, guru harus menciptakan situasi dan kondisi belajar yang kondusif, memahami karakterisistik siswa, serta memotivasi siswa agar siap mengikuti proses pembelajaran. Tujuan pembelajaran matematika di sekolah dasar pada Kurikulum Tingkat Satuan Pendidikan (KTSP) adalah sebagai berikut: (1) memahami konsep matematika, menjelaskan keterkaitan antar konsep dan mengaplikasikan konsep atau alogaritma, secara luwes, akurat, efisien, dan tepat, dalam pemecahan masalah; (2) menggunakan penalaran pada pola dan sifat, melakukan manipulasi matematika dalam membuat generalisasi, menyusun bukti, atau menjelaskan gagasan dan pernyataan matematika; (3) memecahkan maslah yang meliputi kemampuan memahami masalah, merancang model matematika, menyelesaikan model, dan menafsirkan solusi yang diperoleh; (4) mengkomunikasikan gagasan dengan simbol, tabel, diagram, atau media lain untuk memperjelas keadaan atau masalah; dan (5) memiliki sikap menghargai kegunaan matematika dalam kehidupan, yaitu memiliki rasa ingin tahu, perhatian, dan minat dalam mempelajari matematika serta sikap ulet dan percaya diri dalam pemecahan masalah.

Kelipatan suatu bilangan bisa diperoleh dengan cara menambahkan bilangan tersebut dari bilangan sebelumnya atau mengalikan bilangan tersebut dengan 1, 2, 3, 4, dan seterusnya. Faktor suatu bilangan bisa diperoleh dengan menentukan bilangan-bilangan yang membagi habis bilangan tersebut. Cara lain untuk menentukan faktor dari sebuah bilangan adalah dengan menentukan perkalian dua bilangan yang hasilnya merupakan bilangan tersebut. Dengan ketentuan, bilangan yang sama hanya ditulis satu kali.

Metode CTL adalah sebuah proses pendidikan yang bertujuan mendorong para siswa melihat makna di dalam materi akademik yang mereka pelajari dengan cara menghubungkan materi-materi akademik dengan konteks dalam kehidupan keseharian mereka (Johnson, 2006: 67). Menurut Masnur Muslih dalam Istiqomah (2008: 30), pendekatan CTL adalah konsep belajar yang membantu guru mengaitkan antara materi pembelajaran dengan situasi nyata, dan mendorong siswa membuat hubungan antara pengetahuan yang dimilikinya dengan penerapan dalam kehidupan sehari-hari. Dari dua definisi di atas dapat disimpulkan bahwa pendekatan CTL menekankan pada proses mengaitkan antara materi pembelajaran dengan kehidupan siswa agar kegiatan pembelajaran lebih bermakna dan dapat diterapkan oleh siswa dalam kehidupan seharihari.

\section{METODE}

Rancangan penelitian yang digunakan dalam penelitian ini adalah penelitian tindakan kelas (PTK) dengan menggunakan dua siklus tindakan yang di dalamnya terdapat empat tahapan utama kegiatan, yaitu perencanaan, tindakan, pengamatan dan refleksi (Arikunto, 2008). Kegiatan penelitian dilaksanakan dalam dua siklus. Masing-masing terdiri atas dua kali tatap muka untuk siklus I dan satu kali tatap muka untuk siklus II. Langkahlangkah penelitian meliputi: (1) penyusunan perencanaan tindakan; (2) pelaksanaan tindakan; (3) observasi tindakan, dan (4) refleksi atas tindakan yang dilakukan. Lokasi penelitian adalah SDN Pakunden 1 Kota Blitar. Penelitian ini melibatkan 25 siswa kelas IV tahun pelajaran 2015/2016 sebagai sasaran. Penelitian ini dilakukan pada bulan Januari hingga Mei 2016.

Agar dapat mengetahui efektivitas metode CTL terhadap hasil belajar matematika materi faktor dan kelipatan bilangan siswa kelas IV, digunakan teknik tes (pre test dan post test) dan nontes berupa observasi, studi dokumentasi dan wawancara. Data situasi pembelajaran diambil dengan menggunakan dokumentasi dan lembar observasi. 
Data dianalisis menggunakan analisis deskriptif dengan teknik komparasi secara konstan. Hal tersebut karena peneltian ini bertujuan mendeskripsikan keadaan proses pembelajaran dan hasil belajar siswa dengan menggunakan metode CTL untuk meningkatkan hasil belajar matematika materi faktor dan kelipatan bilangan kelas IV. Agar mengetahui dampak penerapan metode CTL pada pemahaman konsep faktor dan kelipatan bilangan, dilakukan analisis deskriptif kuantitatif berdasarkan rata-rata dan persentase. Kriteria penilaian dituangkan pada setiap instrumen tes. Ketuntasan klasikal (kelas) dinyatakan dalam bentuk persentase hasil perbandingan antara jumlah siswa yang tuntas dengan jumlah siswa keseluruhannya.

\section{HASIL DAN PEMBAHASAN}

\section{Hasil}

\section{Siklus I}

Siklus I pertemuan pertama dilaksanakan pada hari Senin, 25 Januari 2016 pada jam pelajaran kedua dan ketiga dengan alokasi waktu 2x35 menit. Kegiatan diawali dengan salam, presensi, apersepsi, mengingatkan kembali materi sebelumnya, menyampaikan tujuan pembelajaran dan memotivasi siswa untuk belajar. Siswa merespon apersepsi dari guru. Siswa bertanya jika ada yang belum dimengerti mengenai materi ajar. Lalu guru membagikan LKS, dimana pada LKS tersebut sudah diajukan masalah kontekstual yang mengarah pada kelipatan suatu bilangan agar siswa termotivasi dan berpikir mengenai alternatif penyelesaian masalah kontekstual tersebut.

Pada kegiatan inti guru menjelaskan materi kelipatan suatu bilangan. Siswa memperhatikan penjelasan guru dan mengajukan pertanyaan jika belum mengerti. Kemudian guru membimbing siswa untuk menentukan kelipatan suatu bilangan melalui LKS siswa. Guru berkeliling kelas untuk mengamati, memotivasi, dan membantu kelompok/ siswa yang mengalami kesulitan. Kemudian siswa berdiskusi dalam kelompok masing-masing untuk menyelesaikan masalah kontekstual dan siswa bertanya jika mengalami kesulitan. Guru memilih beberapa kelompok untuk mempresentasikan hasil diskusinya. Siswa yang terpilih mempresentasikan hasil diskusi kelompoknya dan siswa lain menanggapi. Kemudian guru meluruskan beberapa jawaban siswa yang kurang tepat. Guru memberikan soal latihan yang ada di dalam LKS secara berkelompok kemudian siswa diminta untuk mengerjakan soal latihan yang ada di dalam LKS secara berkelompok. Guru memilih kelompok secara acak untuk menuliskan jawaban kelompoknya.

Pada kegiatan akhir, guru memberikan kuis untuk melihat tingkat penalaran siswa secara individu terhadap materi kelipatan bilangan. Guru membimbing siswa menyimpulkan mengenai kelipatan suatu bilangan dan kelipatan persekutuan dua bilangan. Siswa diberikan PR. Kemudian siswa mengerjakan tes evaluasi secara indivdu. Siswa dengan bimbingan guru menyimpulkan kelipatan suatu bilangan dan kelipatan persekutuan dua bilangan.

Sedangkan pada siklus I pertemuan II dilaksanakan pada hari Kamis, 28 Januari 2016 pada jam pelajaran ke-2 dan ke-3 dengan alokasi waktu 2x35 menit. Kegiatan diawali dengan salam, presensi, apersepsi, mengingatkan kembali materi sebelumnya yaitu faktor suatu bilangan. Guru menyampaikan tujuan pembelajaran dan memotivasi siswa untuk belajar, siswa merespon apersepsi dari guru. Siswa bertanya jika ada yang belum dimengerti bila materi sebelumnya belum dimengerti. Lalu guru membagikan LKS dimana pada LKS tersebut sudah diajukan masalah kontekstual yang mengarah pada faktor suatu bilangan dan siswa termotivasi dan berpikir alternatif penyelesaian masalah kontekstual tersebut.

Pada kegiatan inti guru menjelaskan materi faktor suatu bilangan, siswa memperhatikan penjelasan guru dan mengajukan pertanyaan jika belum mengerti. Kemudian guru membimbing siswa untuk menentukan faktor suatu bilangan melalui LKS siswa. Guru berkeliling kelas untuk mengamati, memotivasi dan membantu kelompok/ siswa yang mengalami kesulitan. Kemudian siswa berdiskusi dalam kelompok masing-masing untuk menyelesaikan masalah kontekstual dan siswa bertanya jika mengalami kesulitan. Guru memilih beberapa kelompok untuk mempresentasikan hasil diskusinya. Siswa yang terpilih mempresentasikan hasil diskusi kelompoknya dan siswa lain menanggapi. Kemudian guru meluruskan 
beberapa jawaban siswa yang kurang tepat. Guru memberikan soal latihan yang ada di dalam LKS secara berkelompok kemudian siswa diminta untuk mengerjakan soal latihan yang ada di dalam LKS secara berkelompok. Guru memilih kelompok secara acak untuk menuliskan jawaban kelompoknya.

Pada kegiatan akhir, guru memberikan kuis untuk melihat tingkat penalaran siswa secara individu terhadap materi faktor suatu bilangan. Guru membimbing siswa menyimpulkan mengenai faktor suatu bilangan dan faktor persekutuan dua bilangan. Siswa diberikan pekerjaan rumah. Kemudian siswa mengerjakan tes evaluasi secara indivdu. Siswa menyimpulkan kelipatan suatu bilangan dan kelipatan persekutuan dua bilangan dengan bimbingan guru.

Kegiatan observasi dilaksanakan selama proses pembelajaran berlangsung. Observasi dilakukan terhadap aktivitas siswa, guru, dan hasil belajar. Hasil belajar siswa yang berupa nilai akhir diperoleh dari nilai proses dan nilai tes akhir pembelajaran. Nilai proses diperoleh dari hasil observasi peneliti terhadap sikap yang ditunjukkan siswa selama mengikuti aktivitas pembelajaran. Hasil observasi aktivitas guru pada siklus I pertemuan pertama sebesar $67 \%$ dan pada pertemuan kedua $80 \%$, sehingga diperoleh rata-rata $73 \%$ (baik). Sedangkan hasil observasi aktifitas siswa pada siklus I pertemuan pertama sebesar $50 \%$ dan pada pertemuan kedua 70\%, sehingga diperoleh rata-rata $60 \%$ (kurang).

Rendahnya aktivitas belajar siswa dikarenakan siswa belum mengenal dan memahami langkah-langkah dalam pembelajaran model CTL. Siswa kurang mampu mengatur waktu dalam mengerjakan tugas yang diberikan guru, sehingga siswa selalu melampaui batas waktu pada saat pengumpulan hasil pekerjaan dan ada sebagian siswa yang masih kurang tepat dalam menjawab pertanyaan yang diberikan guru.

Adapun rekapitulasi nilai tes akhir siswa pada siklus I menunjukan bahwa pembelajaran matematika materi faktor dan kelipatan suatu bilangan yang dilakukan pada siklus I, dari 25 siswa, sebanyak 11 siswa tuntas belajar secara klasikal sedangkan 14 siswa belum tuntas belajar. Ketuntasan belajar klasikal pada siklus I mencapai
44\% dengan kualifikasi kurang sekali.

Hasil dari pelaksanaan siklus I dapat direfleksikan bahwa guru telah melaksanakan kegiatan pembelajaran dengan baik sesuai RPP yang telah dibuat sehingga aktivitas pembelajaran lebih terarah. Meskipun demikian ada beberapa hal yang perlu dilakukan perbaikan demi tercapainya peningkatan hasil belajar pada siklus II. Beberapa hal yang menjadi catatan untuk dilakukan perbaikan adalah: (1) peneliti (guru) belum mampu mengelola waktu dengan baik; (2) siswa merasa kesulitan memahami penyampaian langkah-langkah kegiatan yang guru lakukan; (3) guru perlu menemukan cara untuk membuat siswa lebih antusias dalam mengikuti pelajaran; (4) guru perlu membimbing siswa agar lebih berani dan percaya diri untuk berbicara di depan kelas; dan (5) perlu adanya peningkatan aktifitas guru dalam pembelajaran, salah satunya dalam hal membimbing siswa.

\section{Siklus II}

Siklus II pertemuan pertama dilaksanakan pada hari Senin, 1 Februari 2016 pada jam pelajaran kedua dan ketiga dengan alokasi waktu 2x35 menit. Kegiatan diawali dengan salam, presensi, apersepsi, mengingatkan kembali materi sebelumnya, menyampaikan tujuan pembelajaran dan memotivasi siswa untuk belajar. Siswa merespon apersepsi dari guru. Siswa bertanya jika ada materi ajar yang belum dimengerti. Lalu guru membagikan LKS dimana pada LKS tersebut sudah diajukan masalah kontekstual yang mengarah pada bilangan prima agar siswa termotivasi dan berpikir mengenai alternatif penyelesaian masalah kontekstual tersebut.

Pada kegiatan inti guru menjelaskan materi bilangan prima, siswa memperhatikan penjelasan guru dan mengajukan pertanyaan jika belum mengerti. Kemudian guru membimbing siswa untuk menentukan bilangan prima melalui LKS siswa. Guru berkeliling kelas untuk mengamati, memotivasi, dan membantu kelompok/siswa yang mengalami kesulitan. Kemudian siswa berdiskusi dalam kelompok masing-masing untuk menyelesaikan masalah kontekstual. Siswa bertanya jika mengalami kesulitan. Guru memilih beberapa kelompok untuk mempresentasikan hasil 
diskusinya. Siswa yang terpilih mempresentasikan hasil diskusi kelompoknya dan siswa lain menanggapi. Kemudian guru meluruskan beberapa jawaban siswa yang kurang tepat. Guru memberikan soal latihan yang ada di dalam LKS secara berkelompok, kemudian siswa diminta untuk mengerjakan soal latihan yang ada di dalam LKS secara berkelompok. Guru memilih kelompok secara acak untuk menuliskan jawaban kelompoknya.

Pada kegiatan akhir, guru memberikan kuis untuk melihat tingkat penalaran siswa secara individu terhadap materi bilangan prima. Guru membimbing siswa menyimpulkan mengenai bilangan prima. Siswa diberikan pekerjaan rumah. Kemudian siswa mengerjakan tes evaluasi secara individu. Siswa menyimpulkan bilangan prima dengan bimbingan guru.

Pada siklus I pertemuan II dilaksanakan pada hari Kamis, 4 Februari 2016 pada jam pelajaran ke-2 dan ke-3 dengan alokasi waktu 2x35 menit. Kegiatan diawali dengan salam, presensi, apersepsi, mengingatkan kembali materi sebelumnya yaitu bilangan prima. Guru menyampaikan tujuan pembelajaran dan memotivasi siswa untuk belajar, siswa merespon apersepsi dari guru. Siswa bertanya jika ada yang belum dimengerti bila materi sebelumnya belum dimengerti. Lalu guru membagikan LKS dimana pada LKS tersebut sudah diajukan masalah kontekstual yang mengarah pada kelipatan persekutuan terkecil (KPK) dan siswa termotivasi dan berpikir alternatif penyelesaian masalah kontekstual tersebut.

Pada kegiatan inti guru menjelaskan materi kelipatan persekutuan terkecil (KPK), siswa memperhatikan penjelasan guru dan mengajukan pertanyaan jika belum mengerti. Kemudian guru membimbing siswa untuk menentukan kelipatan persekutuan terkecil (KPK) melalui LKS siswa. Guru berkeliling kelas untuk mengamati, memotivasi dan membantu kelompok/siswa yang mengalami kesulitan. Kemudian siswa berdiskusi dalam kelompok masing-masing untuk menyelesaikan masalah kontekstual dan siswa bertanya jika mengalami kesulitan. Guru memilih beberapa kelompok untuk mempresentasikan hasil diskusinya. Siswa yang terpilih mempresentasikan hasil diskusi kelompoknya dan siswa lain menanggapi. Kemudian guru meluruskan beberapa jawaban siswa yang kurang tepat. Guru memberikan soal latihan yang ada di dalam LKS secara berkelompok kemudian siswa diminta untuk mengerjakan soal latihan yang ada di dalam LKS secara berkelompok. Guru memilih kelompok secara acak untuk menuliskan jawaban kelompoknya.

Pada kegiatan akhir guru memberikan quis untuk melihat tingkat penalaran siswa secara individu terhadap materi kelipatan persekutuan terkecil (KPK). Guru membimbing siswa menyimpulkan mengenai kelipatan persekutuan terkecil (KPK). Siswa diberikan PR. Kemudian siswa mengerjakan tes evaluasi secara indivdu. Siswa dengan bimbingan guru menyimpulkan kelipatan persekutuan terkecil (KPK).

Kegiatan observasi dilaksanakan selama proses pembelajaran berlangsung. Observasi dilakukan terhadap aktivitas siswa, guru, dan hasil belajar. Hasil belajar siswa yang berupa nilai akhir diperoleh dari nilai proses dan nilai tes akhir pembelajaran. Nilai proses diperoleh dari hasil observasi peneliti terhadap sikap yang ditunjukkan siswa selama mengikuti aktivitas pembelajaran yang dilakukan guru serta keterampilan yang ditunjukkan oleh siswa dalam menyelesaikan tugas. Hasil observasi aktivitas guru pada siklus I sebesar $93 \%$ pada pertemuan I dan $100 \%$ pada pertemuan II sehingga diperoleh rata-rata $97 \%$ (amat baik). Sedangkan hasil observasi aktifitas siswa pada siklus I sebesar $90 \%$ pada pertemuan I dan $100 \%$ pada pertemuan II sehingga diperoleh rata-rata 95\% (amat baik).

Tingginya aktivitas belajar siswa dikarenakan siswa telah memahami langkah-langkah dalam pembelajaran menggunakan model CTL, siswa menjadi lebih aktif dan pandai mengatur waktu dalam mengerjakan tugas dengan sebaik-baiknya. Sebagian besar siswa mampu menjawab dengan tepat pertanyaan yang diberikan guru.

Adapun rekapitulasi nilai tes akhir siswa pada siklus I dapat diperoleh informasi bahwa pembelajaran matematika materi bilangan prima dan KPK yang dilakukan pada siklus II dari 25 siswa sebanyak 22 siswa tuntas belajar secara klasikal sedangkan 3 siswa belum tuntas belajar. Ketuntasan belajar klasikal pada siklus II mencapai 
88\% dengan kualifikasi amat baik dan telah memenuhi kriteria ketuntasan belajar yang telah ditetapkan sehingga tidak perlu diadakan siklus lanjutan.

Dari hasil pelaksanaan pembelajaran menentukan bilangan prima dan KPK melalui model CTL pada siklus II terdapat peningkatan yang signifikan terhadap aktifitas siswa, guru dan hasil belajar siswa. Hal tersebut dapat diketahui melalui perbandingan peningkatan ketuntasan belajar secara klasikal dari setiap siklusnya.

\section{Pembahasan}

Berdasarkan observasi, model pembelajaran CTL telah dilaksanakan sesuai dengan langkahlangkah pada rencana pelaksanaan pembelajaran. Temuan aktivitas guru pada pelaksanaan tindakan siklus I yaitu guru telah melaksanakan pembelajaran dengan cukup baik salah satunya adalah guru menjelaskan kegiatan pembelajaran yang akan dilakukan. Guru juga memberikan motivasi kepada siswa agar selalu bersemangat dalam belajar. Hal ini dilakukan untuk menyiapkan dan membimbing siswa agar terlibat aktif dalam pembelajaran dan siswa memiliki motivasi dalam diri mereka untuk belajar sehingga keberhasilan dalam belajar dapat tercapai. Menurut Dimyati dan Mudjiono (2002:43) menjelaskan bahwa motivasi merupakan faktor seperti halnya intelegensi dan hasil belajar sebelumnya yang dapat menentukan keberhasilan belajar siswa dalam bidang pengetahuan, nilainilai dan keterampilan. Berdasarkan pendapat tersebut motivasi serta penjelasan guru mengenai kegiatan pembelajaran matematika melalui model CTL yang akan dilaksanakan sangatlah penting bagi siswa agar siswa jelas dengan kegiatan yang direncanakan oleh guru.

Pembelajaran yang dilaksanakan pada siklus I dan siklus II sesuai dengan Rencana Pelaksanaan Pembelajaran (RPP) yang telah disusun. Secara garis besar, pembelajaran pada siklus I dan siklus II dapat diringkas yaitu: (1) guru memberikan penjelasan tentang faktor dan kelipatan bilangan dan memberikan contoh soal beserta penyelesaiannya, (2) siswa membentuk kelompok dan diberi tugas menyelesaikan soal sesuai petunjuk yang diberikan guru, (3) Siswa mengembangkan atau menciptakan model-model matematis simbolik secara informal terhadap persoalan atau masalah yang diajukan,
(4) Presentasi hasil diskusi, (5) Siswa diberikan latihan soal kemudian guru membahas soal latihan tersebut, (6) siswa menyelesaikan tes evaluasi di akhir kegiatan secara individu. Menurut Muslich, (2009:41) yang mengemukakan pembelajaran CTL adalah konsep belajar yang membantu guru mengaitkan antara materi pembelajaran dengan situasi dunia nyata siswa dan mendorong siswa membuat hubungan antara pengetahuan yang dimilikinya dengan penerapannya dalam kehidupan mereka sehari-hari. Dalam konteks CTL belajar bukan hanya sekedar mendengarkan dan mencatat, akan tetapi belajar merupakan suatu proses berpengalaman secara langsung. Melalui proses berpengalaman itu diharapkan perkembangan siswa terjadi secara utuh, yang tidak hanya berkembang dalam aspek kognitif saja, tetapi juga aspek afektif dan juga psikomotorik.

Penerapan model pembelajaran CTL pada mata pelajaran matematika materi faktor dan kelipatan bilangan pada siklus I sudah berjalan dengan lancar. Guru sudah cukup baik dalam pelaksanaan pembelajaran sesuai dengan RPP yang telah dibuat sebelumnya. Namun masih ada beberapa langkah pembelajaran yang belum dilaksanakan. Dari hasil yang telah diperoleh aktivitas guru pada siklus I pertemuan 1 memperoleh presentase sebesar $67 \%$ dan pada pertemuan 2 memperoleh presentase sebesar $80 \%$, sehingga pada siklus I ketuntasan aktivitas guru mendapatkan rata-rata presentase sebesar $82,5 \%$ dengan kualifikasi baik.

Dari aktivitas pembelajaran siswa pada siklus I, keaktifan siswa dalam pembelajaran sudah mulai muncul. Dari data yang diperoleh, terlihat bahwa presentase aktivitas siswa pada siklus I pertemuan pertama memperoleh presentase sebesar 50\% dan pada pertemuan 2 memperoleh presentase sebesar 70\%, sehingga pada siklus I aktivitas siswa memperoleh presentase rata - rata sebesar $60 \%$. Hal ini menunjukkan bahwa lebih dari 50\% siswa telah menunjukkan aktivitas yang positif pada siklus I ketika diterapkan model pembelajaran CTL. Hal ini didukung dengan hasil angket siswa pada siklus I yang menunjukan, dari 10 pertanyaan yang diajukan mengenai tanggapan siswa tentang penerapan model pembelajaran CTL, rata-rata siswa yang setuju dengan presentase jawaban iya mencapai lebih dari $50 \%$ pada setiap jawaban. Hasil belajar siswa dalam pelaksanan siklus I 
diketahui masih cukup banyak siswa yang belum mencapai krieria kelulusan minimum (KKM) yang ditentukan. Dari 25 siswa dalam kelas pada pertemuan pertama, terdapat 14 siswa (56\%) yang tidak tuntas dan 11 siswa (44\%) yang sudah tuntas, pada pertemuan kedua, terdapat 9 siswa (36\%) yang tidak tuntas dan $16(64 \%)$ siswa yang sudah tuntas.

Dari hasil yang telah diperoleh aktivitas guru pada siklus II menunujukan bahwa guru telah melaksanakan langkah-langkah pembelajaran dengan sangat baik. Hal ini ditunjukkan dengan perolehan presentase aktivitas guru pada pertemuan pertama sebesar $93 \%$ dan pada pertemuan 2 memperoleh presentase sebesar $100 \%$, sehingga pada siklus II ketuntasan aktivitas guru mendapatkan rata-rata presentase sebesar 97\% dengan kualifikasi sangat baik. Dari aktivitas pembelajaran siswa pada siklus II, keaktifan siswa dalam pembelajaran sudah muncul. Dari data yang diperoleh menunujukan presentase aktivitas siswa pada siklus II pertemuan pertama memperoleh presentase sebesar $90 \%$ dan pada pertemuan kedua memperoleh presentase sebesar $100 \%$, sehingga pada siklus I aktivitas siswa memperoleh presentase rata-rata sebesar $95 \%$. Hal ini menunjukkan bahwa siswa telah menunjukkan aktivitas yang lebih positif pada siklus II ketika diterapkan model pembelajaran CTL. Hasil angket respon siswa pada siklus II menunjukan dari 10 pertanyaan yang diajukan, rata-rata siswa setuju dengan presentase jawaban iya mencapai lebih dari $90 \%$ pada setiap jawaban. Hasil belajar siswa dalam pelaksanan siklus II dapat diketahui dari jumlah siswa yang mencapai KKM. Dari 25 siswa dalam kelas pada pertemuan pertama, terdapat 5 siswa (20\%) yang tidak tuntas, dan 20 siswa (80\%) yang sudah tuntas. Pada pertemuan 2 terdapat 1 siswa (4\%) yang tidak tuntas dan 24 (96\%) siswa yang sudah tuntas. Hal ini menunjukkan adanya peningkatan jika dibandingkan dengan perolehan hasil pada siklus I.

Penilaian siswa pada siklus I dan siklus II merupakan nilai afektif dan kognitif pembelajaran, sehingga didapatkan nilai akhir. Nilai afektif tersebut didasarkan pada hasil sikap siswa ketika proses pembelajaran berlangsung. Aspek yang dinilai meliputi toleransi, disiplin, tanggung jawab, dan komunikatif. Nilai kognitif siswa berdasarkan pada perolehan nilai pada hasil kerja kelompok dan hasil tes individu. Pada saat belum dilaksanakan pembelajaran dengan model CTL, hasil belajar siswa masuk ke dalam kategori kurang, yaitu dengan rata-rata kelas yakni 58 dan ketuntasan belajar hanya mencapai $40 \%$. Setelah dilaksanakan pembelajaran dengan model CTL hasil belajar siswa pada siklus I memperoleh rata-rata 71 dan ketuntasan belajar siswa mencapai 44\%. Pada siklus II memperoleh rata-rata 80 dan ketuntasan belajar siswa mencapai $88 \%$.

Berdasarkan temuan yang diperoleh dari aktivitas guru dan siswa maka dapat disimpulkan bahwa penerapan model pembelajaran CTL dapat meningkatkan hasil belajar matematika materi faktor dan kelipatan bilangan pada siswa kelas 4 SDN Pakunden 1 Kota Blitar. Terbukti dari hasil peningkatan pada siklus I ke siklus II yang cukup signifikan. Menurut Johnson (2006) menyatakan bahwa CTL adalah sebuah proses pendidikan yang bertujuan menolong para siswa melihat makna di dalam materi akademik yang mereka pelajari dengan cara menghubungkan subjeksubjek akademik dengan konteks dalam kehidupan keseharian mereka, yaitu dengan konteks keadaan pribadi, sosial, dan budaya mereka. CTL adalah suatu strategi pembelajaran yang menekankan kepada proses keterlibatan siswa secara penuh untuk dapat menemukan materi yang dipelajari dan menghubungkannya dengan situasi kehidupan nyata sehingga mendorong siswa untuk dapat menerapkannya dalam kehidupan mereka (Sanjaya, 2006:255). Pembelajaran dengan model CTL ini akan membantu pemahaman siswa pada materi pelajaran secara teoritis jika dipandang dari penerapan dalam kehidupan sehari-hari. Konten pembelajaran tidak hanya dapat dipahami secara logis oleh kognitif siswa, tetapi siswa dapat menerapkan dan mengalami konsep teori tersebut dalam tindakan praktis. Kegiatan melalui pengamatan dan tindakan yang disesuaikan dengan konsep teori yang ada.

\section{KESIMPULAN DAN SARAN}

\section{Kesimpulan}

Berdasarkan Penelitian Tindakan Kelas (PTK) yang dilakukan pada siswa kelas IV, SDN Pakunden 1 Kota Blitar Tahun Pelajaran 2015/2016, dapat 
ditarik kesimpulan, yaitu penggunaan metode CTL pada mata pelajaran matematika materi faktor dan kelipatan bilangan dapat meningkatkan hasil belajar siswa kelas 4 SDN Pakunden 1 Kota Blitar. Hal ini sesuai dengan nilai hasil belajar siswa pada siklus I dengan rata-rata nilai tes akhir siswa yaitu 71, dengan ketuntasan belajar sebesar $44 \%$. Sedangkan pada siklus II rata-rata nilai tes akhir siswa 80 dengan ketuntasan belajar sebesar $88 \%$. Penerapan model CTL dalam pembelajaran matematika materi faktor dan kelipatan bilangan pada siswa kelas 4 SDN Pakunden 1 Kota Blitar telah dilaksanakan dengan baik dan sesuai dengan langkah-langkah yang ada. Hal ini terbukti dari hasil yang diperoleh, aktivitas guru pada siklus I mendapatkan rata-rata presentase $82,5 \%$, dengan kualifikasi baik. Pada siklus II mendapatkan ratarata presentase $97 \%$ dengan kualifikasi sangat baik.

\section{Saran}

Berdasarkan penelitian tersebut, dapat diketahui bahwa dengan menggunakan model pembelajaran CTLdapat meningkatkan hasil belajar siswa. Maka dari itu. peneliti ingin mengemukakan saran yang dapat menjadi rekomendasi dalam upaya meningkatkan mutu pendidikan di Sekolah Dasar khususnya pada mata pelajaran matematika. Adapun saran yang diberikan sebagai berikut: guru hendaknya menjelaskan tugas yang harus dilakukan siswa sebelum pembentukan kelompok, guru hendaknya selalu memberi motivasi kepada siswa agar mau bekerja sama, saling membantu dalam diskusi kelompok, guru hendaknya selalu memberi motivasi pada siswa agar berani menyampaikan pendapat, pesan mengenai pembelajaran yang telah dilakukan, siswa diharapkan lebih berkonsentrasi dan berpartisipasi aktif selama penerapan model pembelajaran CTL.

\section{DAFTAR RUJUKAN}

Arikunto, S. 2002. Prosedur Penelitian Suatu Pendekatan Praktik. Jakarta: Rineka Cipta.

Dimyati \& Mudjiono. 2002. Belajar dan Pembelajaran. Jakarta: Rineka Cipta.

Istiqomah, L. 2009. Penerapan Pendekatan Konstektual di Kelas. Surabaya: Media.

Johnson, B. E. 2006. Contextual Teaching \& Learning. Bandung: MLC.

Muslich, M. 2009. KTSP Pembelajaran Berbasis Kompetensi dan Kontekstual. Jakarta: Bumi Aksara.

Sanjaya, W. 2006. Strategi Pembelajaran Berorientasi Standar Proses Pendidikan. Jakarta: Kencana Prenada Media Group.

Subarinah. 2006. Inovasi Pembelajaran Matematika. Jakarta: Dirjen Pendidikan Tinggi Direktorat Ketenagaan Depdiknas. 